\title{
岩手大学工学部附属金型技術研究センター 新技術応用展開部門
}

\section{1.はじめに}

岩手大学工学部附属金型技術研究センターは, 平成 15 年 2 月に「基礎研究部門」が盛岡市の岩手大学工学部内に設 置され，同年 5 月に「新技術応用展開部門」が盛岡市から $50 \mathrm{~km}$ ほど南にある北上市にサテライトとして設置された.

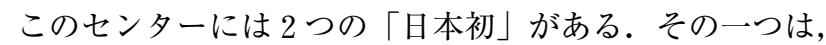
サテライトの設置に関係するが，それまで自治体から国立 大学への寄付は禁じられていたが，平成 14 年 11 月に地方 財政再建促進特別措置法施行令の規制緩和第 1 号で, 北上 市からの寄付金で「新技術応用展開部門」が運営されてい ることである. 二つ目は, 設立当時日本の大学で唯一の「金 型」と名前の付いた研究センターであったことである. 金 型技術は技能的な要素が強く, これまで大学でシステム的 に研究されることはなかったが, 中国に代表される外国よ り先を行く技術を研究し, 発展させるためには組織的な研 究を行う必要がある.

金型技術研究センターの設置目的は，(1)総合技術とし ての金型技術研究の高度化を図る (2) 金型技術研究開発の 国際的な拠点を確立する（金型技術の CEO を目指す）(3) 研究成果を地域産業等に提供する (4) 高度専門技術者の育 成を行う (5) 共同研究を通して地域産業等の国際競争力を 高める，ことである。

スタッフは「基礎研究部門」が専任教員 1 名と兼任教員 10 名で構成されている. 教員の専門分野は, 機械工学科, フロンティア材料機能工学専攻, 材料物性工学専攻から なっており，金型に関する基礎的な要素研究を行っている. 「新技術応用展開部門」は客員教授 2 名 (内常駐 1 名), 助 手 1 名, 技術補佐員 3 名, 事務補佐員 1 名, 連携協力員 5 名 (コーディネーター 1 名, 研究員 4 名), 技術アドバイザー 3 名の計 15 名で運営されており, 地域企業における研究 開発の推進や共同研究での具体的商品開発を行っている.

\section{2 。新技術応用展開部門の概要}

筆者が所属する「新技術応用展開部門」は，前述したよ うに大学本体から $50 \mathrm{~km}$ も離れた北上市にある. 北上市

\footnotetext{
* Kameda, Eiichiro

岩手大学工学部附属金型技術研究センター 新技術応用展開部門 岩手県北上市相去町山田 2-18

北上オフィスプラザ 210 号室（０24-0051）

2006.2.28 受理
}

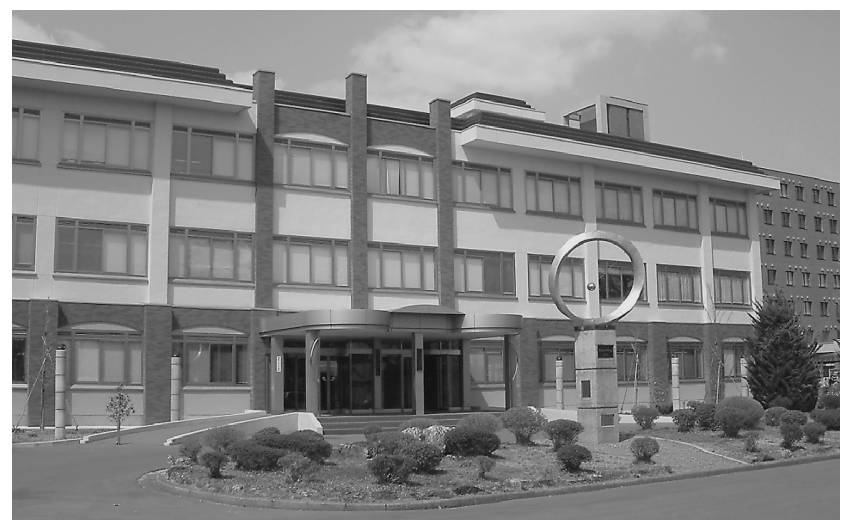

図 1 基礎研究部門（工学部内：盛岡市）

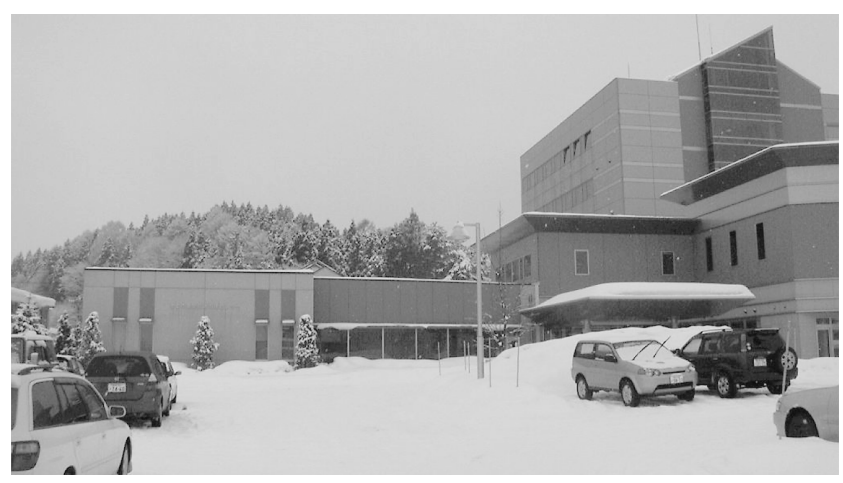

図 2 新技術応用展開部門（北上サテライト）

は人口 9 万人強であるが，岩手県で工業製品出荷高第 1 位 を長く保っていた工業都市であり，しかも金型製造業，金 型部品製造専門業，プレス加工業，成形加工業等，金型関 連企業は 90 社以上あると言われている.そこで北上市が 金型をキーワードに地域企業の技術アップを目指し，大学 を誘致したわけである。

現在「新技術応用展開部門」には，学生はおらず，研究 スタッフだけが在席している，日常業務は, 多くの企業と の共同研究や産学官連携による研究開発プロジェクトを通 して地域に貢献しょうと頑張っている.

\section{3 . 研 究内 容}

研究は, プレス・モールド金型のシミュレーション, 生 産管理, 表面処理, 離型, 摩耗, 商品開発等を行っている が，ここでは新技術応用展開部門の内容を紹介する. 


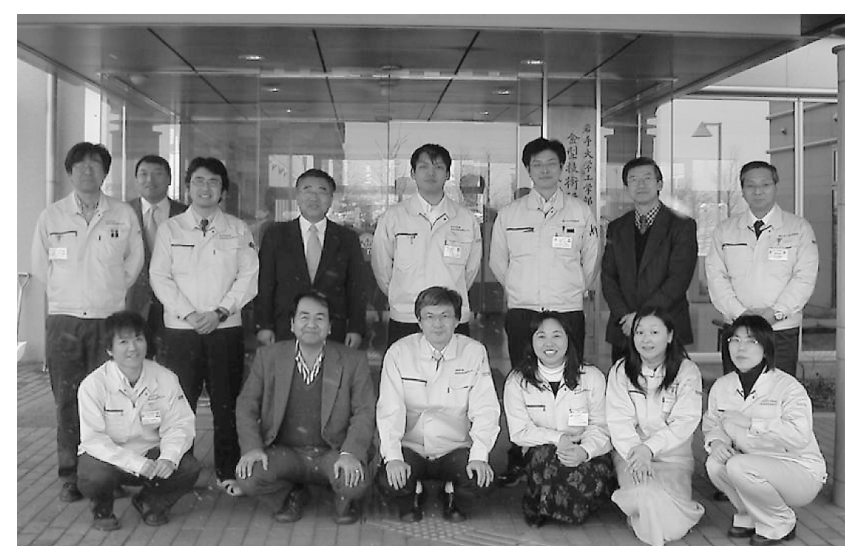

図 3 新技術応用展開部門のメンバー

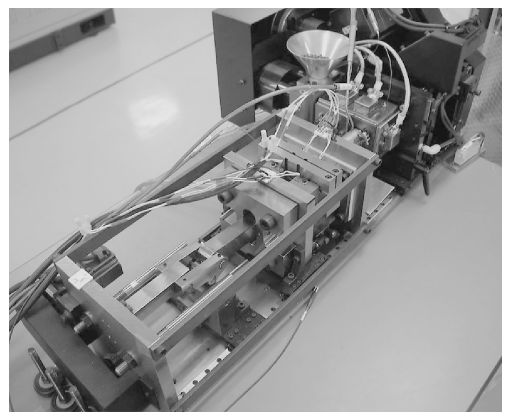

図 4 試作したマイクロ成形機

\section{1 マイクロ成形機の開発}

平成 16 年度・ 17 年度地域新生コンソーシアム研究開発 事業を経済産業省東北経済産業局から委託を受けたもので, 筆者が総括研究代表を務めさせていただいている．卓上型 で微細精密モールド成形用に特化した成形機の開発とその 成形を活用した部品組立の高効率生産手法を目指す生産革 新技術の研究の研究を行っている. この研究には 2 大学, 研究機関 1 , 民間企業 8 社が相互に協力している. 1 年目 は研究開始が遅れ, 実験装置を作ったが試作 1 号機に手が つけられずせっかく頂いた研究予算を使いきれず，残念な 思いをした．今年度も最初は出遅れていたがメーカの協力 でようやく 1 号機ができ，いろいろ初期デー夕を採ってい るところであるが，おもしろいデータが出はじめている.

\section{2 インテリジェント生産システムの研究}

これも平成 17 年度地域新生コンソーシアム研究開発事 業の一部を担当している.これはかなり大きなコンソーシ アムでセンター長の岩㴊がプロジェクトリーダーで山形県 の高分子材料グループ, 岩手県の鋳造グループおよび金型 グループをまとめている。 そして, 副センター長の清水が 金型部門のグループリーダとしてインテリジェント生産シ ステムとしてプレスとモールドのグループに対し，それぞ れ研究会を立ち上げ研究成果を持ち寄って検討している. そこでは製品がプレスや成形機から出たときにその段階で 良否の判定が終了して, 良品だけを取り出せるようなシス テムを目指している。 そのためには材料開発・材料評価, 製品設計, 解析 $(\mathrm{CAE})$, 金型設計, 金型製作, 転写（プ

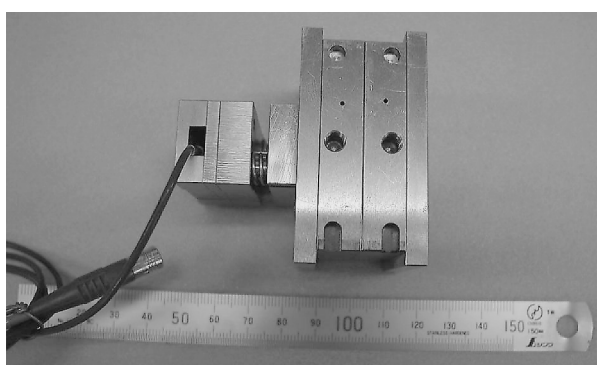

図 5 マイクロ成形機用金型

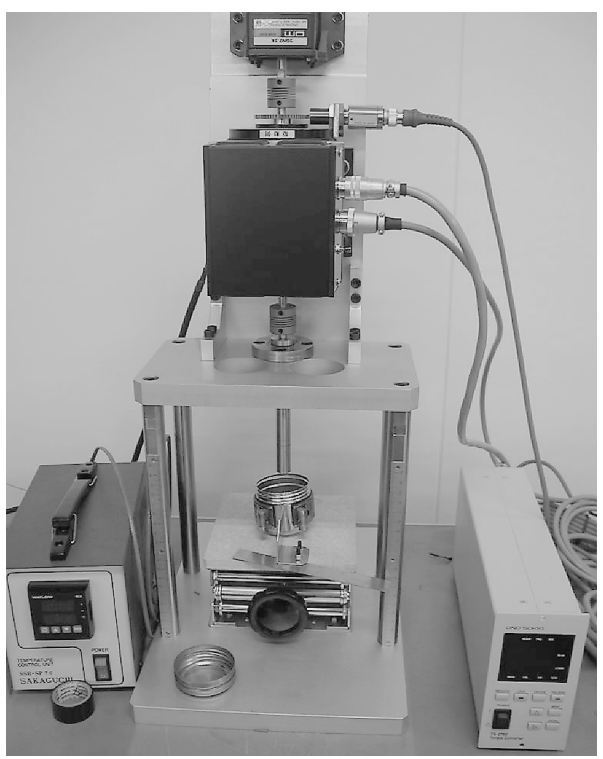

図 6 流動粘度測定装置

レスあるいはモールド成形), センシングの技術を融合し て最適条件での生産と良品の予測をするスケールの大きい 夢のあるシステムである。

\section{3 溶融樹脂と金属の摩擦試験}

溶融しているプラスチック材料が金型表面上を流れてい るときどのくらい抵抗があり，それが温度や速度でどのよ うに変化するかを研究している. 将来的には成形材料や コーティングによる特性, 金型摩耗などを研究したい.

\section{4.おわりに}

金型技術研究センターでは，この他プレス技術の研究や 地域企業をはじめ県内外の企業との共同研究や相互協力に 力を入れている，遠いところではありますが，ぜひ当セン ターに足をお運びいただきたい.

最後に岩手大学では今年 4 月より金型技術研究センター と併設して, 高度専門技術者の育成を行う大学院「金型・ 鋳造工学専攻」を新設する.大学院では金型技術開発の高度 専門技術と経営マネジメントができる人材の育成を計画し ている.こちらについても関心があればご連絡を頂きたい.

\section{参 考 文 献}

1 ）岩㴊 明：岩手大学広報誌， 2(2005) 